\title{
Molecular phylogenetics of shrews (Mammalia: Soricidae) reveal timing of transcontinental colonizations
}

\author{
Sylvain Dubey ${ }^{\mathrm{a}, *}$, Nicolas Salamin ${ }^{\mathrm{a}}$, Satoshi D. Ohdachi ${ }^{\mathrm{b}}$, Patrick Barrière ${ }^{\mathrm{c}}$, Peter Vogel ${ }^{\mathrm{a}}$ \\ a Department of Ecology and Evolution, University of Lausanne, CH-1015 Lausanne, Switzerland \\ ${ }^{\mathrm{b}}$ Institute of Low Temperature Science, Hokkaido University, Sapporo 060-0819, Japan \\ ${ }^{\mathrm{c}}$ Laboratoire Ecobio UMR 6553, CNRS, Université de Rennes 1, Station Biologique, F-35380, Paimpont, France
}

Received 4 July 2006; revised 8 November 2006; accepted 7 December 2006

Available online 19 December 2006

\begin{abstract}
We sequenced 2167 base pairs (bp) of mitochondrial DNA cytochrome $b$ and 16S, and 1390 bp of nuclear genes BRCA1 and ApoB in shrews taxa (Eulipotyphla, family Soricidae). The aim was to study the relationships at higher taxonomic levels within this family, and in particular the position of difficult clades such as Anourosorex and Myosorex. The data confirmed two monophyletic subfamilies, Soricinae and Crocidurinae. In the former, the tribes Anourosoricini, Blarinini, Nectogalini, Notiosoricini, and Soricini were supported. The latter was formed by the tribes Myosoricini and Crocidurini. The genus Suncus appeared to be paraphyletic and included Sylvisorex. We further suggest a biogeographical hypothesis, which shows that North America was colonized by three independent lineages of Soricinae during middle Miocene. Our hypothesis is congruent with the first fossil records for these taxa. Using molecular dating, the first exchanges between Africa and Eurasia occurred during the middle Miocene. The last one took place in the Late Miocene, with the dispersion of the genus Crocidura through the old world.
\end{abstract}

(C) 2006 Elsevier Inc. All rights reserved.

Keywords: Soricidae; Colonization; Miocene; Africa, Asia, America; Phylogeny

\section{Introduction}

Global climate has fluctuated greatly since the Cenozoic, especially between the Late Eocene (40 Myr ago; Ogg, 2004) and the end of the last glacial maximum of the Pleistocene $(11,500 \mathrm{yr})$. The resulting sea level variations and creation of temporary land bridges led to several intercontinental exchanges between the new world and the old world via the Bering Strait (Hunt, 2004). It is commonly acknowledged that Cenozoic intercontinental exchanges between Africa and Eurasia occurred during the Miocene-Pliocene transition ( $5 \mathrm{Myr}$ ) via a land bridge situated at the actual Gibraltar Strait that was caused by the Messinian salinity crisis that partly dried out the Mediterranean sea (Azzaroli and Guazzone, 1979; Thomas et al.,

\footnotetext{
${ }^{*}$ Corresponding author. Fax: +41216924165.

E-mail address: sylvain.dubey@unil.ch (S. Dubey).
}

1982; Chevret, 1994). Most of these observations are based on fossil data, especially of large mammals, whose fossils are more easily preserved through time (Alroy, 2003). For small mammals, the situation is different because fewer fossil data are available. Molecular phylogenetic analyses coupled with recent advances in relaxing molecular clock (e.g., Sanderson, 1997, 2002; Thorne and Kishino, 2002) can help put estimated divergence times on nodes without fossils. They are therefore very useful to resolve migration history of such taxa (e.g., Beerli and Edwards, 2002). This is particularly true with shrews (Soricidae, Eulipotyphla), because of their very poor and incomplete fossil record. Any reconstruction of their biogeographic history is therefore largely dependent on the comparison of living species (Butler, 1998).

Here, we analysed a sample of species from the Soricidae, which is one of the largest mammalian clade with more than 300 described species. It has recently been divided into three subfamilies (Hutterer, 2005). The Soricinae 
(red-toothed shrews), which are mainly distributed in the Holartic region, contain 146 species split into 13 genera. The Crocidurinae (white-toothed shrews), which have diversified in Africa and Eurasia contain 210 described species distributed in nine genera. Finally, the Myosoricinae from Africa contain 18 species and three genera (Hutterer, 2005). Despite this diversity, much of the variations observed are not particularly useful for taxonomic purposes, which makes species assignment often problematic and can render discriminant characters at supra-generic levels difficult to find.

The most seminal paper published by Repenning (1967) recognized the importance of the mandibular articulation and allowed the grouping of three genera with white teeth (Anourosorex, Chimarrogale and Nectogale) within the "red-toothed" Soricinae. However, uncertainties remained at three important levels. First, within the African shrews, the basal position of Myosorex, which shows a plesiomorphic dental formula, is not clearly demonstrated. This taxon was included by Repenning (1967) and Hutterer (1993) in Crocidurinae (tribe Myosoricini), but it was recently considered, with Congosorex and probably Surdisorex, as a different subfamily (Myosoricinae; Hutterer, 2005). Second, the relationships between Suncus Ehrenberg, 1832 and Crocidura Wagler, 1832 remains unclear. The latter shows a reduction of one unicuspid, which is usually considered as derived and it is not clear if the reduction occurred independently several times (Heim de Balsac and Lamotte, 1957; Butler, 1998). Third, uncertainties remain in the taxonomic delimitation of the tribe Neomyini, from which Reumer $(1987,1998)$ proposed to extract two other tribes, the Anourosoricini and the Notiosoricini. $\mathrm{He}$ also proposed to separate the Blarinellini tribe from the Soricini (Reumer, 1998).

Beside classical morphology, techniques such as karyology and biochemical systematics based on enzyme electrophoresis allowed much progress on species level assignment (Catzeflis et al., 1985; Maddalena, 1990; Maddalena and Bronner, 1992; Ivanitskaya, 1994; Maddalena and Ruedi, 1994; Ruedi and Vogel, 1995; Ruedi, 1996; Zima et al., 1998; Schlitter et al., 1999). This resulted in a clarification of the basal position of Myosorex, which suggested the creation of the Myosoricinae subfamily (Maddalena and Bronner, 1992; Hutterer, 2005). More recently, mitochondrial DNA (mtDNA) sequences allowed a much finer resolution (George, 1988; George and Sarich, 1994; Ohdachi et al., 1997, 2001; Ruedi et al., 1998; Fumagalli et al., 1999; Motokawa et al., 2000; Brant and Orti, 2002; Han et al., 2002; Vogel et al., 2003; Ohdachi et al., 2004; Dubey et al., 2006; Dubey et al., in press). At supra-generic level, complex relationships emerged with paraphyletic, and or polyphyletic taxa, (e.g., for the basal African Crocidurinae; Quérouil et al., 2001). The latter conclusions based on mtDNA were, however, often not supported. Nevertheless, in our most recent study on Soricinae (Ohdachi et al., 2006), the support was adequate at a tribe level, partially confirming the concept of Reumer (Soricini, Neomyini, Notiosoricini (1987, 1998)), but Anourosorex was placed in an unexpected basal position (Anourosoricinae). Such results may be due to misleading information in mitochondrial genes at higher taxonomic level, a situation that has led to erroneous phylogenetic trees for other mammals (Janke et al., 1997) and for fishes (Rasmussen and Arnason, 1999).

In this study, we aim at understanding the higher taxonomic level within the Soricidae using two nuclear and two mitochondrial markers. The lower mutation rate of nuclear genes is expected to help obtaining a good resolution at a higher taxonomic level such as subfamilies, tribes, and genera, while the two mitochondrial markers will allow a good resolution at lower taxonomic level such as intrageneric relationships. Based on the trees obtained, we analysed the potential origin of the different major clades, as well as the number of transcontinental exchanges, using molecular dating and reconstruction of biogeographic area of origins. Our goal was to unravel the diversification history of the family.

\section{Materials and methods}

\subsection{Sampling}

We analysed 81 samples of Soricidae, five of Erinaceidae, six of Talpidae, and as outgroup a more distant Laurasiatheria, the Common Pipistrelle (Pipistrellus pipistrellus).

Within the Soricinae, all the tribes were represented in our analyses, and we included ten of the thirteen genera recognized by Hutterer (2005). Within the Crocidurinae, the three most widespread genera (Crocidura, Suncus, and Sylvisorex) were represented. The rare and monospecific genera Scutisorex and Ruwenzorisorex from Africa (formerly considered as Sylvisorex) and Ferroculus and Solisorex from Highlands of Sri Lanka were not treated in the present study. Within the Myosoricinae, only samples of Myosorex were analysed. Thus, Congosorex, formerly considered as Myosorex (two species), and Surdisorex (two species) were not treated. For the tribes or the genus Sorex containing species on several continents, representative on each ones were analysed.

The samples included material from the following collections: Lausanne (IZEA), Switzerland; Paimpont (Station Biologique), France; and Sapporo (Hokkaido University), Japan (Table 1).

\subsection{DNA extraction and amplification}

IZEA samples were first frozen in the field in liquid nitrogen and kept for several years at $-70{ }^{\circ} \mathrm{C}$ before being stored in ethanol until DNA extraction. Samples from the other collections were directly stored in ethanol. DNA extraction was carried out using the QIA Amp DNA Mini Kit (Qiagen). Double-stranded DNA amplifications of the mitochondrial cytochrome $b$ gene $(c y t-b)$ and $16 \mathrm{~S}$ ribosomal sequence were performed with the 
Table 1

Species and specimens used in the present study, specimen identification code for each species (ID), geographic origin of the samples and area code for the biogeographic reconstruction analysis (1: Eurasia, 2: Africa, 3: North America), collection code, and GenBank accession number of the published $c y t-b$ sequences of Ohdachi et al. (2006) used in our study

\begin{tabular}{|c|c|c|c|c|c|}
\hline Genus & Species & $\begin{array}{l}\text { Specimen identification } \\
\text { code }\end{array}$ & $\begin{array}{l}\text { Origin and biogeographic } \\
\text { code }\end{array}$ & $\begin{array}{l}\text { Collection } \\
\text { code }\end{array}$ & $\begin{array}{l}\text { GenBank accession } \\
\text { of published } c y t-b \text { sequence }\end{array}$ \\
\hline Anourosorex & squamipes & 1 & CN, Wollung Valley (Yunnan), 1 & $\mathrm{~T} 4738$ & \\
\hline Anourosorex & yamashinai & 1 & TW, Nantou Co., 1 & ASTW.I & AB175088 \\
\hline Anourosorex & yamashinai & 2 & TW, Chiayi Co., 1 & ASTW.2 & AB175089 \\
\hline Blarina & brevicauda & 1 & US, Michigan State, 3 & 02.7 .23 .1 & \\
\hline Blarina & brevicauda & 2 & US, Michigan State, 3 & BLB.I & AB175134 \\
\hline Blarinella & griselda & 1 & VN, Mt. Tay Con Linh II, 3 & BLG & AB175144 \\
\hline Chimarrogale & himalayica & 1 & VN, Ha Tinh, Huong Son, 1 & VIET.CHV & AB175094 \\
\hline Chimarrogale & platycephala & 1 & JP, Nagasaki Pref., 1 & IZEA 7610 & \\
\hline Chimarrogale & platycephala & 2 & TW, Nantou Co., 1 & 3.3 .15 .1 & \\
\hline Chodsigoa & caovansunga & 1 & VN, Mt. Tay Con Linh II, 1 & $\mathrm{COC} 1$ & $\mathrm{AB} 175104$ \\
\hline Chodsigoa & caovansunga & 2 & VN, Mt. Tay Con Linh II, 1 & $\mathrm{COC} 2$ & AB175103 \\
\hline Chodsigoa & parca & 1 & VN, Mt. Tay Con Linh II, 1 & COPI & AB175105 \\
\hline Chodsigoa & parca & 2 & VN, Mt. Tay Con Linh II, 1 & $\mathrm{COP} 2$ & $\mathrm{AB} 175106$ \\
\hline Chodsigoa & sodalis & 1 & TW, Kao-Hsiung Co., 1 & SIS.2 & AB175102 \\
\hline Chodsigoa & sodalis & 2 & TW, Chiayi Co., 1 & SIS.I & AB127978 \\
\hline Cryptotis & goldmani & 1 & Mexico, Gurrero State, 3 & $\mathrm{X} 2$ & AB175138 \\
\hline Cryptotis & magna & 1 & Mexico, Oaxaca State, 3 & $\mathrm{X} 4$ & AB175141 \\
\hline Cryptotis & parva & 1 & US, Texas State, 3 & CRPI & $\mathrm{AB} 175135$ \\
\hline Episoriculus & fumidus & 1 & TW, Chiayi Co., 1 & SIF.2 & AB175108 \\
\hline Episoriculus & fumidus & 2 & TW, Nantou Co., 1 & SIF.I & AB175107 \\
\hline Neomys & anomalus & 1 & $\mathrm{CH}$, Sion, 1 & IZEA 5524 & \\
\hline Neomys & anomalus & 2 & YU, Popova Sapka, 1 & IZEA 1367 & \\
\hline Neomys & anomalus & 3 & PT, Unhais da Serra Covilha, 1 & IZEA 5919 & \\
\hline Neomys & fodiens & 1 & YU, Popova Sapka, 1 & IZEA 1368 & \\
\hline Neomys & fodiens & 2 & IT, Laghi di Ceretto, 1 & IZEA 5643 & \\
\hline Neomys & fodiens & 3 & CN, Parc Nat. Altaï, 1 & IZEA 7453 & \\
\hline Neomys & fodiens & 4 & $\mathrm{CH}$, Bassins, 1 & IZEA 5686 & \\
\hline Notiosorex & crawfordi & 1 & US, Texas State, 3 & NSC2 & AB175146 \\
\hline Notiosorex & crawfordi & 2 & US, Texas state, 3 & NSCI & $\mathrm{AB} 175145$ \\
\hline Sorex & alpinus & 1 & $\mathrm{CH}$, Pont-de-Nant, 1 & IZEA 5444 & \\
\hline Sorex & araneus & 1 & SK, Bratislava, 1 & IZEA 5744 & \\
\hline Sorex & araneus & 2 & CN, Parc Nat. Altaï, 1 & IZEA 7452 & \\
\hline Sorex & cinereus & 1 & US, 3 & 99.9 .19 .1 & \\
\hline Sorex & cinereus & 2 & US, 3 & 99.9 .21 .1 & \\
\hline Sorex & excelsus & 1 & $\mathrm{CN}$, Qinghai, 1 & MSI 4456 & \\
\hline Sorex & excelsus & 2 & $\mathrm{CN}$, Qinghai, 1 & MSI 4470 & \\
\hline Sorex & fumeus & 1 & US, 3 & PA110 & \\
\hline Sorex & fumeus & 2 & US, Pennsylvania State, 3 & SEF.I & AB175116 \\
\hline Sorex & granarius & 1 & ES, Rascafria, 1 & IZEA 639 & \\
\hline Sorex & isodon & 1 & FI, Iisalmi, 1 & IZEA 5622 & \\
\hline Sorex & minutus & 1 & $\mathrm{CH}$, Champmartin, 1 & IZEA 7622 & \\
\hline Sorex & raddei & 1 & TR, Sumela, 1 & IZEA 6080 & \\
\hline Sorex & radde $i$ & 2 & TR, Sumela, 1 & IZEA 6081 & \\
\hline Sorex & saussurei & 1 & MX, Guerrero State, 3 & SESA2 & AB175118 \\
\hline Sorex & saussurei & 2 & MX, Guerrero State, 3 & SESA1 & AB175117 \\
\hline Sorex & volnuchini & 1 & TR, Sumela Altindere, 1 & IZEA 6079 & \\
\hline Crocidura & brunnea & 1 & ID, Java/Cibodas, 1 & IZEA 4549 & \\
\hline Crocidura & buettikoferi & 1 & BF, Adiopodoumé, 2 & IZEA 2409 & \\
\hline Crocidura & leucodon & 1 & TR, Altindere, 1 & IZEA 6040 & \\
\hline Crocidura & malayana & 1 & MY, Ulu Gombak, 1 & IZEA 3550 & \\
\hline Crocidura & nanilla & 1 & CI, Lamto, 2 & IZEA 2530 & \\
\hline Crocidura & negligens & 1 & MY, Tioman, 1 & IZEA 3557 & \\
\hline Crocidura & nigripes & 1 & ID, Bore Katimbo Sulavesi, 1 & IZEA 4400 & \\
\hline Crocidura & olivieri & 1 & BF, Bangui, 2 & IZEA 2821 & \\
\hline Crocidura & orientalis & 1 & ID, Java/Cibodas, 1 & IZEA 4551 & \\
\hline Crocidura & shantungensis & 1 & JP, Tsushima Isl., 1 & IZEA 7510 & \\
\hline Crocidura & suaveolens & 1 & HU, Fülophasa, 1 & IZEA 6732 & \\
\hline Crocidura & theresae & 1 & BF, Bobo Dioulasso, 2 & IZEA 3092 & \\
\hline Crocidura & viaria & 1 & BF, Oursi, 2 & IZEA 3108 & \\
\hline Suncus & dayi & 1 & IN, Avallanchi, 1 & IZEA V562 & \\
\hline
\end{tabular}


Table 1 (continued)

\begin{tabular}{|c|c|c|c|c|c|}
\hline Genus & Species & $\begin{array}{l}\text { Specimen identification } \\
\text { code }\end{array}$ & $\begin{array}{l}\text { Origin and biogeographic } \\
\text { code }\end{array}$ & $\begin{array}{l}\text { Collection } \\
\text { code }\end{array}$ & $\begin{array}{l}\text { GenBank accession } \\
\text { of published } c y t-b \text { sequence }\end{array}$ \\
\hline Suncus & dayi & 2 & IN, Avallanchi, 1 & IZEA V567 & \\
\hline Suncus & dayi & 3 & IN, Kotagiri, 1 & IZEA V576 & \\
\hline Suncus & etruscus & 1 & FR, Camargue/Le Pèbre, 1 & IZEA 5462 & \\
\hline Suncus & etruscus & 2 & IT, Fivizzano c/o Farina, 1 & IZEA 5641 & \\
\hline Suncus & montanus & 1 & IN, Kotagiri, 1 & IZEA V573 & \\
\hline Suncus & murinus & 1 & IN, 1 & IZEA V546 & \\
\hline Suncus & murinus & 2 & IN, Masinagudi, 1 & IZEA V554 & \\
\hline Suncus & murinus & 3 & JP, Okinawa, 1 & SUN2 & AB175074 \\
\hline Suncus & remyi & 1 & GA, Moueva, 2 & SBP GA3650 & \\
\hline Suncus & varilla & 1 & $\mathrm{ZA}, 2$ & IZEA “4” & \\
\hline Suncus & varilla & 2 & $\mathrm{ZA}, 2$ & IZEA “3” & \\
\hline Sylvisorex & johnstoni & 1 & GA, Doudou Mounts, Moueva, 2 & SBP GA3691 & \\
\hline Sylvisorex & johnstoni & 2 & GA, Doudou Mounts, Moueva, 2 & SBP GA3695 & \\
\hline Sylvisorex & johnstoni & 3 & GA, Doudou Mounts, Moueva, 2 & SBP GA3648 & \\
\hline Sylvisorex & ollula & 1 & GA, Doudou Mounts, Moueva, 2 & SBP GA3586 & \\
\hline Myosorex & cafer & 1 & ZA, Serala Prov. Nature Res., 2 & GB40764 & \\
\hline Myosorex & sclateri & 1 & ZA, Natal, Matubatuba, 2 & GB40382 & \\
\hline Myosorex & sclateri & 2 & ZA, Natal, Matubatuba, 2 & GB40359 & \\
\hline Myosorex & varius & 1 & ZA, Natal, Ngome Forest, 2 & GB39824 & \\
\hline Myosorex & varius & 2 & ZA, Pretoria, 2 & GB41102 & \\
\hline Myosorex & varius & 3 & $\mathrm{ZA}$, Pretoria, 2 & GB41086 & \\
\hline Erinaceus & europaeus & 1 & $\mathrm{CH}$, Lausanne, 1 & IZEA dorigny & \\
\hline Hylomys & parvus & 1 & ID, Sumatra, 1 & IZEA 4494 & \\
\hline Hylomys & parvus & 2 & ID, Sumatra, 1 & IZEA 4495 & \\
\hline Hylomys & parvus & 3 & ID, Sumatra, 1 & IZEA 4493 & \\
\hline Hylomys & parvus & 4 & ID, Sumatra, 1 & IZEA 4484 & \\
\hline Euroscaptor & mizura & 1 & JP, Aomori Prefecture, 1 & 01.5 .26 .2 & \\
\hline Talpa & caeca & 1 & $\mathrm{CH}$, Bellinzone, 1 & IZEA 5968 & \\
\hline Talpa & caeca & 2 & $\mathrm{CH}$, Bellinzone, 1 & IZEA 5976 & \\
\hline Talpa & europea & 1 & $\mathrm{CH}$, Meride, 1 & IZEA 5972 & \\
\hline Uropsilus & $s p$ & 1 & $\mathrm{CN}$, Wollung Valley (Yunnan), 1 & IZEA T4739 & \\
\hline Uropsilus & $s p$. & 2 & $\mathrm{CN}$, Wollung Valley (Yunnan), 1 & IZEA T4743 & \\
\hline Pipistrellus & pipistrellus & 1 & $\mathrm{CH}$, Préverenges, 1 & IZEA 5408 & \\
\hline
\end{tabular}

Abbreviations of countries: BF, Burkina Faso; CI, Ivory Coast; CH, Switzerland; CN, China; ES, Spain; FI, Finland; FR, France; GA, Gabon; HU, Hungary; ID, Indonesia; IN, India; IT, Italy; JP, Japan; MY, Malaysia; MX, Mexico; PT, Portugal; SK, Slovakia; TR, Turkey; TW, Taiwan; US, United States of America; VT, Vietnam; YU, Yugoslavia; ZA, South Africa.

primer pairs L14724/H15149, C1/C2, C3/H15915, and L14724/H15915 (see Irwin et al., 1991; Dubey et al., 2006), and 16 sf ( $5^{\prime} \mathrm{cct}$ acc gag cet ggt gat ag $\left.3^{\prime}\right) / 16 \mathrm{Srbis}$ $\left(5^{\prime}\right.$ ata gat aga aac cga cct gg $\left.3^{\prime}\right)$, specifically developed for this study. Amplification of the Breast cancer susceptibility 1 (BRCA1) and Apolipoprotein B (ApoB) nuclear genes (exons) were performed using the primer pairs, B1f/B1r (Dubey et al., 2006) and ApoBf (5' gca atc att tga ctt aag $\left.\operatorname{tg} 3^{\prime}\right) / \mathrm{ApoBr}\left(5^{\prime}\right.$ gag caa caa tat ctg att gg $3^{\prime}$ ), specifically developed for this study. Amplification conditions for the $c y t-b, 16 \mathrm{~S}$, and BRCA1 consisted of 35 thermal cycles (40 for BRCA1) of $60 \mathrm{~s}$ denaturation (30 s for the primers pairs L14724/H15149, C1/C2, C3/ $\mathrm{H} 15915)$ at $94{ }^{\circ} \mathrm{C}, 60 \mathrm{~s}$ (45 s for the primers pairs $\mathrm{L} 14724 / \mathrm{H} 15149, \mathrm{C} 1 / \mathrm{C} 2, \mathrm{C} 3 / \mathrm{H} 15915)$ annealing at $50{ }^{\circ} \mathrm{C}$ for $c y t-b\left(52^{\circ} \mathrm{C}\right.$ for BRCA1, and $55^{\circ} \mathrm{C}$ for $\left.16 \mathrm{~S}\right)$ and $120 \mathrm{~s}$ (60 s for the primers pairs L14724/H15149, C1/ $\mathrm{C} 2, \mathrm{C} 3 / \mathrm{H} 15915)$ extension at $72^{\circ} \mathrm{C}$. Amplification conditions for the ApoB gene consisted of 40 cycles of $45 \mathrm{~s}$ denaturation at $94{ }^{\circ} \mathrm{C}, 45 \mathrm{~s}$ annealing at $50{ }^{\circ} \mathrm{C}$ and $90 \mathrm{~s}$ extension at $72{ }^{\circ} \mathrm{C}$.
PCR products were checked on a $1 \%$ agarose electrophoresis gel and visualised with ethidium bromide staining to verify PCR quality. Products were then purified by centrifugal dialysis using the QIAquick PCR Purification Kit (Qiagen), according to the manufacturer's instructions.

Cycle sequencing was performed in $10 \mu$ total volume containing $1-3 \mu \mathrm{l}$ of amplified DNA, $1 \mu \mathrm{l}$ of $10 \mu \mathrm{M}$ primer, $4 \mu \mathrm{l}$ of ABI PRISM ${ }^{\mathrm{TM}}$ Dye Terminator 1 (Perkin-Elmer). Sequence reactions were visualised on an ABI 3100 genetic analyser (Applied Biosystems).

\subsection{Phylogenetic analyses}

The sequences were aligned using the multiple alignment algorithm implemented in ClustalW (Thompson, 1994), and further checked by eye. Due to the problems associated with the ILD test (Yoder et al., 2001; Struck et al., 2006; Wheeler et al., 2006), the congruence between the four markers was tested by performing 100 bootstrap resamples on each marker and comparing the support level thus obtained for each node. The four DNA sequences were combined only if all 
supported nodes (defined here by bootstrap values $>75 \%$ ) were present in all four obtained trees (e.g., Barrett et al., 1991; Huelsenbeck et al., 1996; Mason-Gamer and Kellogg, 1996; Cunningham, 1997; Halanych, 1998; Struck et al., 2006). Maximum parsimony analyses on the complete data set were performed using Paup*4.0b10 (Swofford, 2001) with 10,000 random addition sequence followed by TBR branch swapping, and keeping at most 100 trees at each replicate. Support values were estimated using 1000 bootstrap resamples using the same heuristic settings. For maximum likelihood (ML) and Bayesian analyses (BA), the models of DNA substitution were selected for each DNA region using dt_modsel (Minin et al., 2003). The GTR + G (Rodriguez et al., 1990; Yang, 1996) model best fitted the combined data set formed by the concatenation of the four sequences. Fast ML heuristic searches and bootstrap analyses (1000 replicates) were performed on the combined data set only using PHYML (Guindon and Gascuel, 2003). Bayesian analyses were performed with a partition specific models, using MrBayes version 3.0 b4 (Huelsenbeck et al., 2001). The HKY85 + G + I model (Hasegawa et al., 1985; Yang, 1996) was used for the $16 \mathrm{~S}$ and $c y t-b$ partition and the GTR $+\mathrm{G}$ for the ApoB and BRCA1 partition. Four independent runs were performed, each consisting of four parallel MCMC chains of five millions generations. Trees were sampled every 1000 generations. The first 3000 trees were discarded as burnin. Both ML and BA analyses were performed on the Vital-IT cluster (Swiss Institute of Bioinformatics).

\subsection{Molecular dating}

The calibration points used for dating the trees was the oldest known Soricinae-Crocidurinae ancestors (20 Myr, Reumer, 1989, 1994), the oldest known Cryptotis (9 Myr BP; Harris, 1998), and Otisorex (3.5 Myr BP; Maldonado et al., 2001). Position of fossils in the tree is shown in Fig. 2. The tree with the highest posterior probability found by MrBayes (see above) was selected as the "true" topology for the molecular dating and a Bayesian approach was used to estimate absolute divergence time. The variance-covariance matrix of rates of substitution of each data partition was estimated as implemented in the software estbranch (Thorne and Kishino, 2002). The four matrices were then used to estimate the divergence time with the program multidivtime (Thorne and Kishino, 2002). The fossil calibration points were used as a lower bound constraint, and the root of the tree was constrained to be at most $50 \mathrm{Myr}$ old (required by the software). Two independent runs were done to assess convergence. In each run, a one million generation chain was run, sampling every 100 generations. All the analyses were ran on the Vital-IT cluster (Swiss Institute of Bioinformatics).

\subsection{Reconstruction of biogeographic origin}

To infer the possible biogeographic origin of the Soricidae and different genera, we reconstructed ancestral geographical origins of each clades with a maximum likelihood approach using Mesquite 1.05 (Maddison and Maddison, 2004). The current geographic distribution of extant species was coded as, (1) for Eurasian taxa, (2) for African taxa, and (3) for North American taxa (Table 1). The model of character evolution was a simple stochastic model (Mk1; Lewis, 2001), which assumes a symmetric and equal rate of change between any two states. The probability that a character changes along a branch of the tree is then a function of the branch length, a change being more likely on longer branches than on shorter ones. Here, we used the calibrated tree obtained by molecular dating (see section above) in order to have branch lengths representing absolute time of divergence.

\section{Results}

\subsection{Phylogenetic relationships}

The 93 sequences of $3577 \mathrm{bp}$ (on which $338 \mathrm{bp}$ were excluded from the analyses) used in this study showed 1892 variable sites, of which 1638 were parsimony-informative. GenBank accession numbers are as follows: for $c y t-b, \quad$ DQ630379-DQ630437, DQ42541, DQ521043DQ521045, DQ065609, DQ065611, for 16S, DQ630291DQ630378, for BRCA1, DQ630209-DQ630290, and for ApoB, DQ630122-DQ630208. Other cyt-b sequences were taken from our previous study (Ohdachi et al., 2006; see Table 1). The alignment file is deposited on TreeBASE under the submission ID number SN3114. The congruence test showed that no nodes with bootstrap higher than $75 \%$ were contradicted by another partition of the data (data not shown). We thus considered that the four markers could be combined for further analyses. Using the combined data matrix, trees obtained by ML, MP, and BA showed identical supported clades. Consequently, only the tree obtained by ML on the complete dataset is shown in Fig. 1. All families, subfamilies, and tribes (Fig. 1) were monophyletic and were supported by $100 \%$ bootstrap, for MP, ML, and a posterior probability of 1.0 for BA (branches support is always cited in the same order in the text, i.e., bootstrap for $\mathrm{MP}$, ML, and posterior probability for BA). All genera, except Suncus, were also supported by all analyses (support of $>78 \%,>83 \%$ and 1.0; Fig. 1). Using a vespertilionid bat as outgroup, the Talpidae was the most basal clade, followed by the Erinaceidae, which is the sister clade of the Soricidae (support of $95 \%, 80 \%$, and 1.0 for the Talpidae, and $100 \%, 100 \%$ and 1.0 for the Erinaceidae). Within the Soricidae, the Crocidurinae and Myosoricinae (sensu Hutterer, 2005) were both monophyletic (support of each subfamily of $100 \%, 100 \%$ and 1.0 ), and clustered together (support of $100 \%, 100 \%$ and 1.0 ), formed a sister clade to the Soricinae (support of $100 \%, 100 \%$ and 1.0). Within the Crocidurinae, the genus Suncus was 


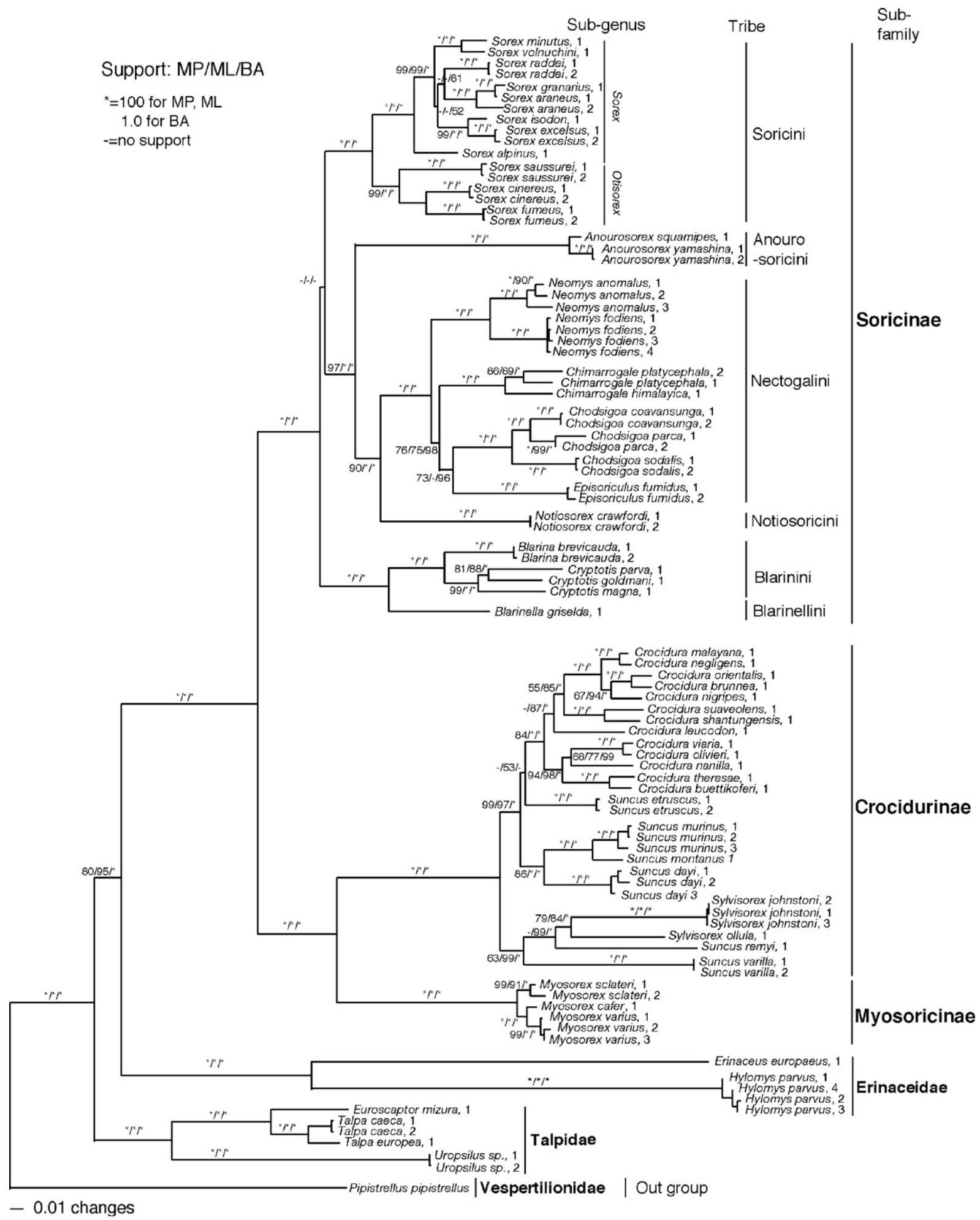

Fig. 1. Phylogeny of the 3314 bp analysed with maximum likelihood, using the TVM + G model of substitution and TBR branch swapping. Values in branches are supports, for the major branches for maximum parsimony (MP) and maximum likelihood (ML) analyses, and Bayesian posterior probabilities (BA). Specimens codes are as in Table 1.

paraphyletic. The African Suncus ( $S$. varilla and $S$. remyi) and the representatives of the genus Sylvisorex ( $S$. ollula, S. johnstoni) formed a basal clade (support of $63 \%, 99 \%$ and 1.0; Fig. 1) to the Asiatic Suncus (S. dayi, S. montanus, S. murinus; support of $86 \%, 100 \%$ and 1.0). The pygmy white-toothed shrew Suncus etruscus was found to be the sister group of the monophyletic genus Crocidura (support of $<50 \%, 53 \%$ and $<0.5$ ).

Three major clades are included in the Soricinae subfamily. The first contained the Soricini tribe, where 
the subgenera Sorex, and Otisorex were monophyletic (support of $100 \%, 100 \%$ and 1.0 , and $100 \%, 99 \%$ and 1.0 , respectively). The second corresponded to the Blarinini and Blarinellini tribes (support of 100\%,100\% and 1.0). Finally, the third included the Anourosoricini tribe that is basal to the Notiosoricini, and the Nectogalini (Hutterer, 2005; former Neomyini, Hutterer, 1993) tribes. Within this latter tribe, the genus Neomys is the sister clade to all other genera (support of $90 \%, 100 \%$ and 1.0 ).

\subsection{Molecular dating}

The two independent runs of MCMC (Markov chain Monte Carlo) gave very similar results (Pearson correlation $=0.98)$ and the major dates obtained during the first analysis are shown below. The separation between Soricidae tribes occurred during the middle Miocene between 16.5 Myr (95\% CI: $12.5-20.5)$ and $13.8 \mathrm{Myr}(95 \% \mathrm{CI}$ : 10.2-17.4) ago (Fig. 2). The separation of the Palaearctic and Nearctic Soricinae happened during the same period, i.e., between Otisorex and Sorex $13.9 \mathrm{Myr}$ ago $(95 \%$ CI: 10.2-17.5), Notiosoricini and Nectogalini $13.8 \mathrm{Myr}$ ago
(95\% CI: 10.2-17.4), and Blarinella, Blarina and Cryptotis 12.1 Myr ago (95\% CI: 5.1-17.7).

The split between the Myosoricinae and Crocidurinae occurred 16.5 Myr ago (95\% CI: 12.5-20.5). The split between the basal African Crocidurinae clade (Sylvisorex, and Suncus) and the Eurasian Suncus occurred $10.8 \mathrm{Myr}$ ago (95\% CI: 7.6-14.0) whereas the split between this latter and the genus Crocidura happened more recently around 9.3 Myr ago (95\% CI: 6.4-12.3). Finally, the split between Eurasian and African Crocidura occurred in the Late Miocene around $8.0 \mathrm{Myr}$ (95\% CI: 5.4-10.7).

\subsection{Biogeographic reconstruction}

The common pipistrelle that was chosen as outgroup to reconstruct the phylogenetic trees was removed because of the difficulty to assign a biogeographic area for its distribution. It is furthermore a very distant taxa of the studied families.

Therefore, the Erinaceidae and Talpidae were the most basal groups for the biogeographic reconstruction. Fig. 3a shows the results of the ancestral biogeographic

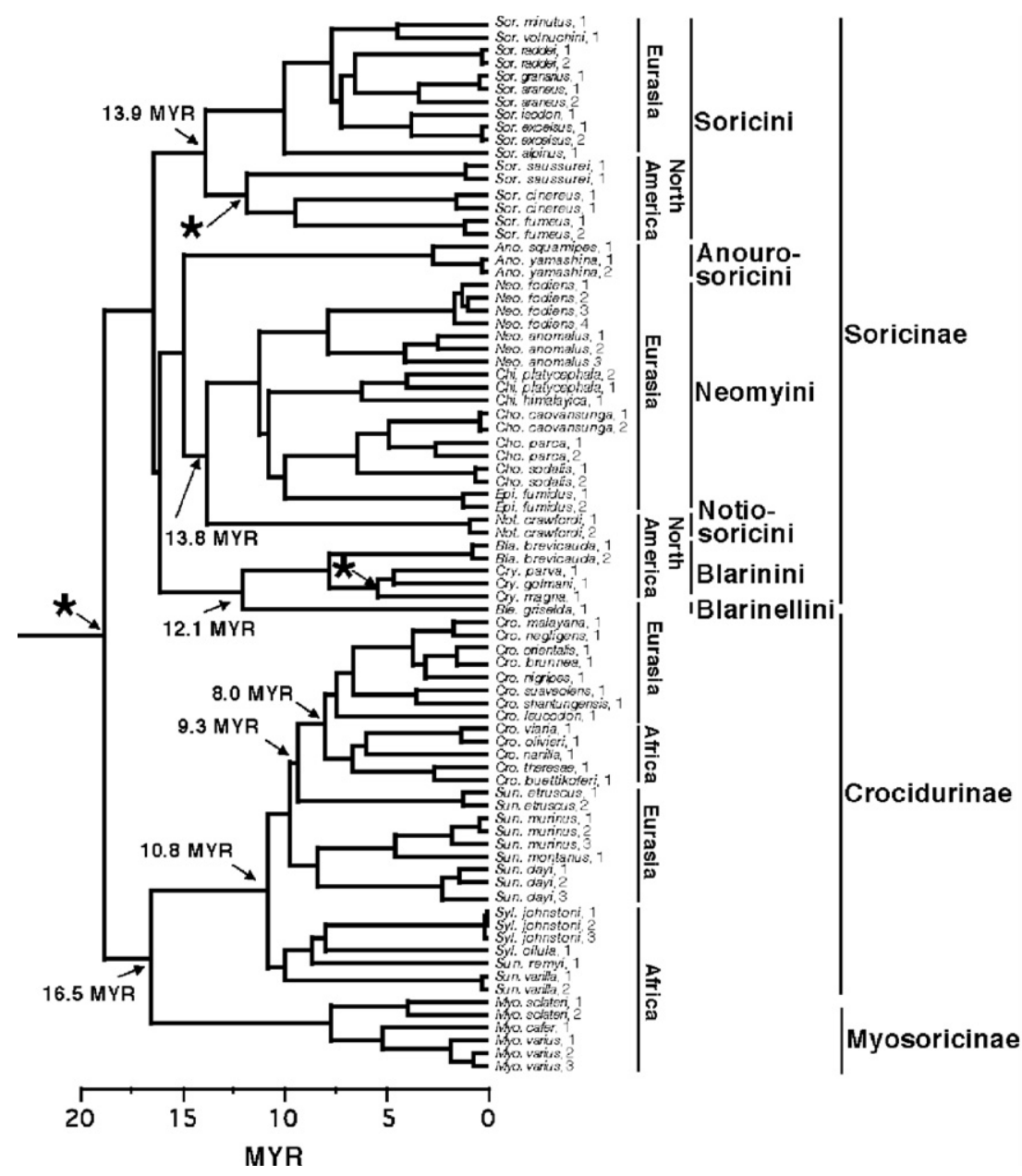

Fig. 2. Molecular dating of splits. The stars indicate the calibration points that were taken as a lower bound on the indicated node. Specimens codes are as in Table 1, and genus abbreviations are Sor. for Sorex, Ano. for Anourosorex, Neo. for Neomys, Chi. for Chimarrogale, Cho. for Chodsigoa, Epi. for Episoriculus, Not. for Notiosorex, Bla. for Blarina, Cry. for Cryptotis, Ble for Blarinella; Cro. for Crocidura, Sun. for Suncus, Syl. for Sylvisorex, Myo. for Myosorex. 
a

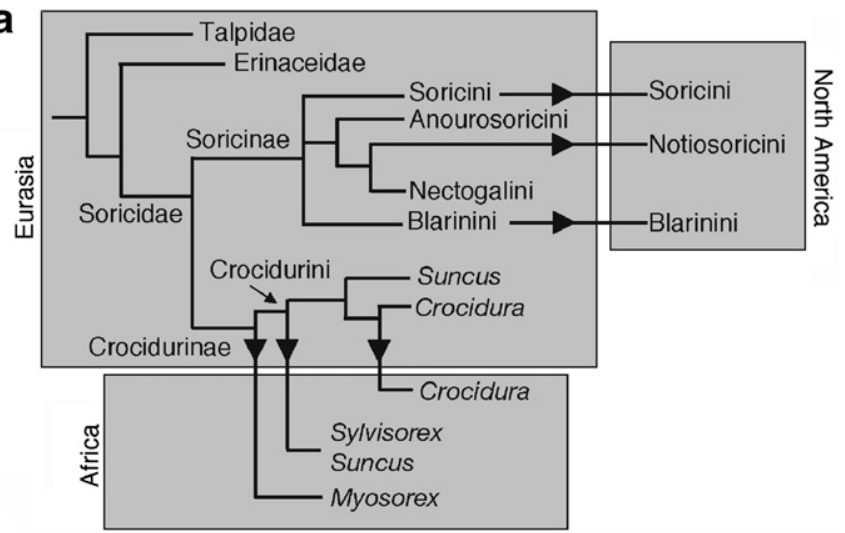

b
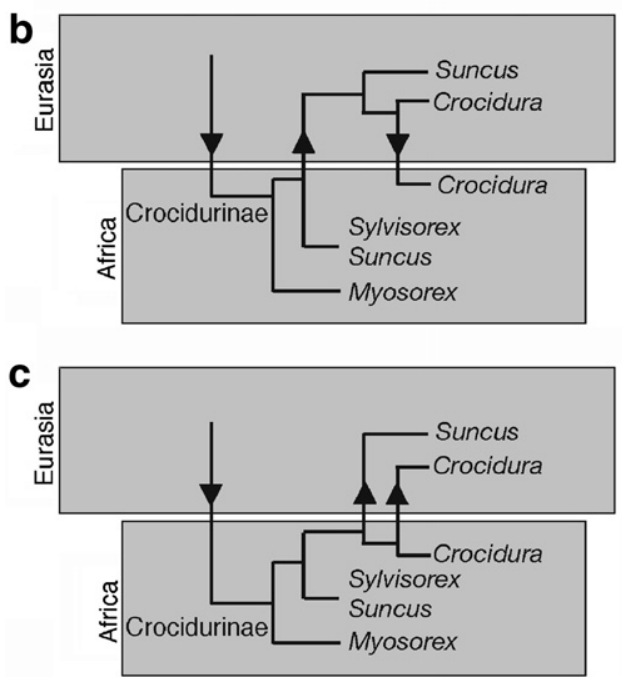

Fig. 3. Hypothesized history of shrews based on the present phylogeny (no time scale), taking into account for the biogeographic analysis (a) and alternative scenarios for the Crocidurinae, only based on fossils records, see Section $4.2(\mathrm{~b}, \mathrm{c})$

origins based on maximum likelihood reconstruction of ancestral areas. The Crocidurinae-Myosoricinae-Soricinae ancestor presents a probability of $99.5 \%$ of being Eurasian, and the basal nodes of Soricinae, and Crocidurinae a probability of, respectively, $99.9 \%$ and $76.4 \%$ of being of Eurasian origin. The basal nodes between American and Eurasian Soricinae, i.e., Notiosoricini vs Nectogalini, Otisorex vs Sorex, and Cryptotis and Blarina vs Blarinella have a probability of, respectively, $99.8 \%, 98.1 \%$, and $95.6 \%$ of being Eurasian. The basal nodes within Otisorex, and between Blarina and Cryptotis have a probability of, respectively, $94.9 \%$ and $98.6 \%$ of being of American origin. Concerning the Crocidurinae, the basal nodes of Crocidurini have a ML prob. of $74.9 \%$ of being Eurasian. The basal node of the Eurasiatic Suncus and Crocidura, and the basal node to the previous genus have a ML prob. of $99.4 \%$, and $99.3 \%$ of being Eurasian. The basal nodes of the African taxa, i.e., Myosorex, Sylvisorex, African Suncus, and African Crocidura have probabilities up to $96 \%$ of being of an African origin.

\section{Discussion}

\subsection{Molecules vs morphology}

The Talpidae, which were considered by most morphologists as sister group to the Soricidae and part of the Eulipotyphla (Simpson, 1945; Macphee and Novacek, 1993; Symonds, 2005), are replaced in our results by the Erinaceidae (Fig. 1), which are represented in this study by two subfamilies (Erinaceinae, and Galericinae). This position was also supported by recent studies based on nuclear genes (Murphy et al., 2001; Douady and Douzery, 2003).

With the combined DNA regions used in this study, the Soricinae were found as sister group to the Crocidurinae (sensu Repenning, 1967; Fig. 1). This position confirmed the classical hypothesis of Repenning (1967).

Although Myosorex formed a monophyletic group, its definition as a distinct subfamily (Maddalena and Bronner, 1992; Quérouil et al., 2001; Hutterer, 2005) cannot be advocated from our results. The genetic distance, expressed by the branch lengths, is comparable to those of different tribes of Soricinae. This close relationship with Crocidurinae (sensu Hutterer, 2005) contrasts with Querouil's results (2001) that tend to cluster the Myosorex with Soricinae on the basis of 16SrRNA data. However, their results were not well supported.

Similarly, the classification of the Anourosorex in a distinct subfamily (Ohdachi et al., 2006) was not supported by our analysis (Fig. 1), the Anourosorex being in a central position within the Soricinae. Thus, we propose to attribute a tribe level for these two clades, which should be named, respectively, Myosoricini (included within the Crocidurinae; Repenning, 1967), and Anourosoricini (included within the Soricinae). The term Myosoricini (Crocidurinae), and Anourosoricini (Soricinae) will be used in the rest of the discussion and in Fig. 3.

Within the Soricinae, five tribes received bootstrap support of $100 \%, 100 \%$ and posterior probabilities of 1.0 (Fig. 1). As in Repenning (1967), the Soricini remained a basal tribe, but Blarinella does no longer belong to it (Fig. 1). The split between the Eurasian subgenus Sorex and the American subgenus Otisorex confirmed earlier hypotheses (Fumagalli et al., 1999; Ohdachi et al., 2006). Furthermore, the Asian genus Blarinella, should not be placed in a separate tribe Blarinellini (Reumer, 1998; Hutterer, 2005), as it was found to be the sister taxon of the American genera Blarina and Cryptotis (support of $100 \%, 100 \%$ and of 1.0, Fig. 1). This position confirmed the hypothesis of Thomas (1911) and some of our previous results (Ohdachi et al., 2006). Consequently, Blarinella will be considered in the rest of the discussion and in Fig. 3 as a member of the Blarinini tribe. Moreover, the Neomyini (Repenning, 1967) should be split into three tribes, as proposed by Reumer (1998): (i) the Nectogalini (Hutterer, 2005) with Neomys basal to Chodsigoa, Episoriculus, and Chimarrogale; this last genus being basal to Chodsigoa and Episoriculus, (ii) the Notiosoricini, and (iii) the Anourosoricini (support of $100 \%, 100 \%$, and of 1.0 
for each tribe, Fig. 1). The relationships between the Soricini, the Blarinini and the other tribes remained unresolved (Fig. 1).

Within the Crocidurini, the genus Suncus appeared paraphyletic, the African species forming a basal clade with the genus Sylvisorex Thomas, 1904, which is strictly confined to Africa. In contrast, the three Asian species ( $S$. dayi, $S$. montanus, and S. murinus) formed a monophyletic clade (support of $100 \%, 86 \%$, and 1.0, Fig. 1), clustered with the pygmy white-toothed shrew, Suncus etruscus, which is basal to the monophyletic genus Crocidura (support of $<50 \%$, $53 \%$ and of $<0.5$, Fig. 1). These results are in agreement with two molecular studies using the mitochondrial $c y t-b$ gene or 16S (Quérouil et al., 2001; Ohdachi et al., 2006), which suggested that none of the Suncus species are included within Crocidura.

Consequently, as the type species of the genus Suncus is the Asian Suncus murinus (Linnaeus, 1766), the Eurasian Suncus should then conserve their taxonomic status. However, the position of the African clade represented by the genera Suncus and Sylvisorex is not yet clearly understood, and no morphological synapomorphies are yet known to define these clades. The analyses of additional species of these genera are needed to unravel their phylogenetic relationships and draw systematic conclusions. This also applies to the questionable position of the monospecific genera Scutisorex Thomas, 1913, and Ruwenzorisorex Hutterer, 1986, whose type specimens were first described as Sylvisorex somereni Thomas, 1910, and Sylvisorex suncoides Osgood, 1936, respectively.

\subsection{Biogeography}

Our study is the first molecular biogeographic reconstruction of the Soricidae, based on molecular dating and reconstruction of biogeographic area of origin. We should note that the biogeographic analyses are based on a simple model. The exchanges between continents are considered as equiprobable in both directions, and they can occur at any time. Under these assumptions, the family originated in Eurasia as suggested by fossils records (Repenning, 1967; Rzebik-Kowalska, 1998; Storch et al., 1998). North America was colonized by three independent lineages of Eurasian Soricinae (Fig. 3) during the middle Miocene (from 13.9 to $12.1 \mathrm{Myr}$, Fig. 2). These events are congruent with the first fossil records of the genera Cryptotis and Notiosorex in North America between 9 and 12 Myr (Harris, 1998), and with the molecular study of Fumagalli et al. (1999) for the subgenera Otisorex. They occurred after the climatic transition from 14.8 to $16.0 \mathrm{Myr}$, which was marked by major shortterm variations in global climate and a global low sea level between 14.8 and 12.9 Myr (Flower and Kennett, 1994). This led to the formation of a land connection between Siberia and Alaska through the Bering Strait. These intercontinental colonizations are contemporary to those of other taxa such as felids (Tedford et al., 1987; Hunt, 2004; Wang et al., 2004), but older than major colonizations of both continents by small and big mammals (Late Miocene, e.g., 7 and 4.5 Myr, and since $9 \mathrm{Myr}$; Tedford et al., 1987; Hunt, 1998; Webb and Opdyke, 1995; Tedford and Martin, 2001; and Van der Made et al., 2002).

According to the biogeographic reconstruction and the molecular dating (Fig. 3a), the first diversification of the monophyletic Crocidurinae occurred in Eurasia, where they differentiated in Crocidurini and Myosoricini (16.5 Myr, 95\% CI: 12.5-20.5; middle Miocene; Figs. 2 and 3). The Myosoricini were the first Soricidae to colonize Africa in the Upper Miocene. Our result coincides with the first fossil record of "Myosorex sp." in Africa (12 Myr; Robinson and Black, 1974), and could be associated with the presence of forested corridors during the Neogene connecting Africa and Asia, $19 \mathrm{Myr}$ ago (Thomas, 1985; Cox and Moore, 1993), as previously suggested by Quérouil et al. (2001). This was also hypothesized for bats (Juste et al., 1999), and is in accordance with the colonization of Africa by the Muridae (Butler, 1984; Jacobs, 1985).

In the late middle Miocene, two other Eurasian lineages emerged (10.8 Myr, 95\% CI: 7.6-14.0). One colonized Africa and differentiated in the actual Sylvisorex and in the African "Suncus" as hypothesized by Butler (1998). Another one differentiated in Eurasia leading to the actual Eurasian Suncus. From this last lineage emerged Crocidura (9.3 Myr, 95\% CI: 6.4-12.3) in Eurasia. Thus, the origin of Crocidura is anterior to the oldest European and Asian fossils known, respectively, of the early Pliocene (5 Myr) and the middle Pleistocene (Rzebik-Kowalska, 1998; Storch et al., 1998). Nevertheless, the discovery in Africa of two very different Crocidura fossils, dating of the middle Pliocene (3 Myr; Butler, 1998), suggests that the diversification of the genus took place much earlier on this continent. This discrepancy illustrated the very poor and incomplete fossil record of the family, which could lead to erroneous interpretations. The reconstruction of its biogeographic history is therefore largely dependent on the comparison of living species (Butler, 1998). Finally, in the Late Miocene, the genus differentiated in an African and an Eurasian lineage (8.0 Myr, 95\% CI: 5.4-10.7), which is older than the Messinian regression. This differentiation corresponds with the beginning of a more humid phase (Late Tortonian) when savannah and subtropical grasslands replaced the Sahara desert (Griffin, 1999, 2002; Micheels, 2003). This created a potential route of colonization between Eurasia and Africa through the middle east, rather than Gibraltar, as suspected by several authors (Azzaroli and Guazzone, 1979; Thomas et al., 1982; Chevret, 1994). Nevertheless, additional Crocidura species should be analysed to test for the presence of two distinct biogeographic lineages, and not one undifferentiated, as suggest by Quérouil et al. (2001). Under this scenario, three independent colonizations from Eurasia to Africa occurred during the Miocene (Fig. 3a).

Without taking into account the biogeographic analysis, two alternative equally parsimonious scenario can be proposed (Fig. 3b and c). (i) First colonization of Africa 
16.5 Myr ago (95\% CI: 12.5-20.5) led to the actual Myosorex, Sylvisorex, and African Suncus. Then, a back colonization happened from Africa to Eurasia, leading to the actual Asian Suncus and Crocidura. Some Crocidura then migrated back to Africa to diversify into the actual African Crocidura (Fig. 3b). (ii) First colonization of Africa 16.5 Myr ago (95\% CI: 12.5-20.5) led to the actual Myosorex, Sylvisorex, African Suncus, and African Crocidura. Then, two successive back colonizations occurred from Africa to Eurasia, first by the African Suncus, and second by the African Crocidura, leading to the actual diversity of Eurasian Suncus and Crocidura (Fig. 3c).

These scenarios imply that the ancestral Crocidurinae disappeared from Eurasia, and were replaced by the lineage emerging from Africa. This hypothesis is supported by the presence during the lower and middle Miocene of a very rich Soricinae fauna in Eurasia and in North Africa, from where they have since disappeared. In contrast, only one doubtful Crocidurinae fossil is known from Eurasia (Turkey; Engesser, 1980; Storch et al., 1998; Rzebik-Kowalska, 1998). The first biogeographic scenario is in agreement with a former hypothesis of Butler (1998), who proposed that three different lineages emerged from Asia and colonized Africa (actual Myosoricini, Suncus and the other Crocidurini). However, this is in contrast with several authors (Meester, 1953; McLellan, 1994; Quérouil et al., 2001) who gave an African origin to the genus Suncus. The first two biogeographic scenarios proposed (Fig. 3a and b) also contradict all the former assumptions concerning Crocidura evolution, who pled for an African origin of this genus (Butler, 1998; Meester, 1953; McLellan, 1994; Quérouil et al., 2001).

Nevertheless, the three scenarios have two points in common. They all hypothesize: (i) a colonization of Africa during the middle Miocene, and (ii) two independent origins of the Crocidura lineages.

Thus, at least three exchanges occurred between Africa and Eurasia, first in the middle Miocene, and second in the Late Miocene with the dispersion of the genus Crocidu$r a$ through the old world. Nevertheless, more investigations are needed. Additional material from, for example, Crocidura, Suncus and endemic African genera such as Scutisorex, as well as the enigmatic Asian genera Ferroculus and Solisorex, should be included in further analyses. These taxa are of major interest to select between these three biogeograhic hypotheses for the Crocidurinae.

\section{Conclusions}

We highlight for the first time a clear relationship between the major groups of taxa within the Soricidae. Anourosorex should be definitively classified inside the Soricinae and not in a different subfamily. Accordingly, Myosorex should be included in the Crocidurinae. Our results also suggest a complex relationship between Suncus and Sylvisorex. Suncus is a paraphyletic unit including at least two Eurasian clades and an African one, the latter comprising Sylvisorex. It therefore needs a taxonomic revi- sion. The biogeographic analyses showed a clear pattern inside the Soricinae, which originated in Eurasia and colonized subsequently North America with three different lineages. However, part of the biogeographical history of Crocidurinae remains uncertain.

\section{Acknowledgments}

We acknowledge M. Colyn, G. Bronner, C. Denys, R.S. Hoffmann, P.D. Jenkins, C.D. Lynch, T. Maddalena, E. Paradis, T. Galewski, and M. Ruedi for providing tissue samples, and N. Di Marco for laboratory work. This work was supported by the Herbette Foundation, University of Lausanne.

\section{References}

Alroy, J., 2003. Taxonomic inflation and body mass distributions in North American fossil mammals. J. Mammal. 84, 431-443.

Azzaroli, A., Guazzone, G., 1979. Terrestrial mammals and land connections in the Mediterranean before and during the Messinian. Palaeogeogr. Palaeoclimatol. Palaeoecol. 29, 155-167.

Barrett, M., Donoghue, M.J., Sober, E., 1991. Against consensus. Syst. Zool. 40, 486-493.

Beerli, P., Edwards, S.V., 2002. When did the Neanderthals and modern humans diverge? Centenary Anniversary Anthropology Institute University of Zurich (1999), Supplement Evolutionary Anthropology.

Brant, S.V., Orti, G., 2002. Molecular phylogeny of short-tailed shrews, Blarina (Insectivora: Soricidae). Mol. Phylogenet. Evol. 22, 163-173.

Butler, P.M., 1984. Macroscelidea, insectivora and chiroptera from the Miocene of EastAfrica. Paleovertebrata 14, 117-200.

Butler, P.M., 1998. Fossil history of shrews in Africa. In: Wojcik, J.M., Wolsan, M. (Eds.), Evolution of Shrews. Mammal Research Institute, Polish Academy of Science, Bialowieza, pp. 121-132.

Catzeflis, F., Maddalena, T., Hellwing, S., Vogel, P., 1985. Unexpected findings on the taxonomic status of East Mediterranean Crocidura russula Auct (Mammalia, Insectivora). Z. Saugetierkd.-Int. J. Mamm. Biol. 50, 185-201.

Chevret, P., 1994. Etudeévolutive des Murinae (rongeurs: mammifères) africains par hybridation ADN/ADN: Comparaison avec les approches morphologiques et paléontologiques, Ph.D. dissertation, University of Montpellier II, Montpellier.

Cox, C.B., Moore, P.D., 1993. Biogeography: An Ecological and Evolutionary Approach. Blackwell Sci., Oxford, pp. 298.

Cunningham, C.W., 1997. Is congruence between data partitions a reliable predictor of phylogenetic accuracy? Empirically testing and iterative procedure for choosing among phylogenetic methods. Syst. Biol. 46, $464-478$.

Douady, C.J., Douzery, E.J.P., 2003. Molecular estimation of eulipotyphlan divergence times and the evolution of "Insectivora". Mol. Phylogenet. Evol. 28, 285-296.

Dubey, S., Zaitsev, M., Cosson, J-F., Abdukadier, A., Vogel, P., 2006. Pliocene and Pleistocene diversification and multiple refugia in a Eurasian shrew (Crocidura suaveolens group). Mol. Phylogenet. Evol. 38, 635-647.

Dubey, S., Antonin, M., Denys, C., Vogel, P., (in press). Use of phylogeny to resolve the taxonomy of the widespread and highly polymorphic African giant shrews (C. olivieri group, Crocidurinae, Mammalia). Zoology.

Engesser, B., 1980. Insectivora und Chiroptera (Mammalia) aus dem Neogen der Türkei. Schweizerische Paläontologische Abhandlungen, vol. 102, 149 pp.

Flower, B.P., Kennett, J.P., 1994. The middle Miocene climatic transition, East Antarctic ice sheet development, deep ocean circulation and global carbon cycling. Palaeogeogr. Palaeocl. 108, 537-555. 
Fumagalli, L., Taberlet, P., Stewart, D.T., Gielly, L., Hausser, J., Vogel, P., 1999. Molecular Phylogeny and Evolution of Sorex Shrews (Soridae: Insectivora) Inferred from Mitochondrial DNA Sequence Data. Mol. Phylogen. Evol. 11, 222-235.

George, S.B., 1988. Systematics, historical biogeography, and evolution of the genus Sorex. J. Mol. Evol. 41, 952-957.

George, S.B., Sarich, V.M., 1994. Albumin evolution in the Soricinae and its implications for the phylogenetic history of the Soricidae. In: Merit, J.F., Kirkland, G.L., Rose, R.K. (Eds.), Advances in the Biology of Shrews, Special Publ., Carnegie Museum of Natural History, Pittsburgh, PA, pp. 289-294.

Griffin, D.L., 1999. The late Miocene climate of northeastern Africa: Unravelling the signals in the sedimentary succession. J. Geol. Soc. Lond. 156, 817-826.

Griffin, D.L., 2002. Aridity and humidity: two aspects of the late Miocene climate of North Africa and the Mediterranean. Palaeogeogr. Palaeocl. $182,65-91$.

Guindon, S., Gascuel, O., 2003. A simple, fast, and accurate algorithm to estimate large phylogenies by maximum likelihood. Syst. Biol. 52, 692-704.

Halanych, K.M., 1998. Considerations for reconstructing metazoan history: signal, resolution, and hypothesis testing. Am. Zool. 38, 929-941.

Han, S.H., Iwasa, M.A., Ohdachi, S.D., Oh, H.S., Suzuki, H., Tsuchiya, K., Abe, H., 2002. Molecular phylogeny of Crocidura shrews in northeastern Asia: a special reference to specimens on Cheju Island, South Korea. Acta Theriol. 47, 369-379.

Harris, A.H., 1998. Fossil history of shrews in North America. In: Wojcik, J.M., Wolsan, M. (Eds.). Mammal Research Institute, Polish Academy of Science, Bialowieza, pp. 121-132.

Hasegawa, M., Kishino, H., Yano, T., 1985. Dating the human-ape split by a molecular clock of mitochondria! DNA. J. Mol. Evol. 22, 160-174.

Heim de Balsac, H., Lamotte, M., 1957. Evolution et phylogénie des Soricidés africains-II. Mammalia 21, 16-46.

Huelsenbeck, J.P., Bull, J.J., Cunningham, C.W., 1996. Combining data in phylogenetic analysis. Trends Ecol. Evol. 11, 152-158.

Huelsenbeck, J.P., Ronquist, F., Nielsen, R., Bollback, J.P., 2001. Evolution: Bayesian inference of phylogeny and its impact on evolutionary biology. Science 294, 2310-2314.

Hunt, R.M., 1998. Ursidae. Date. In: Janis, C., Scott, K., Jacobs, L. (Eds.), Evolution of Tertiary mammals of North America. Cambridge University Press, New York, pp. 174-195.

Hunt, R.M., 2004. Global climate and the evolution of large mammalian. Carnivores during the later cenozoic in North America. Bulletin American Museum of Natural History 285, 139-156.

Hutterer, R., 1993. Order Insectivora. In: Wilson, D.E., Reeder, D.M. (Eds.), Mammal Species of the World: A Taxonomic and Geographic Reference, second ed. Smithsonian Institution Press, Washington, DC, pp. $69-130$.

Hutterer, R., 2005. Order Soricomorpha. In: Wilson, D.E., Reeder, D.M. (Eds.), Mammal Species of the World: A Taxonomic and Geographic Reference, third ed. Smithsonian Institution Press, Washington, DC, pp. 220-311.

Irwin, D.M., Kocher, T.D., Wilson, A.C., 1991. Evolution of the cytochrome $b$ gene of Mammals. J. Mol. Evol. 32, 128-144.

Ivanitskaya, E.Y., 1994. Comparative cytogenetics and systematics of Sorex: a cladistic approach. pp. 313-323. In: Merritt, J.F., Kirkland, G.L., Jr., Rose, R.K. (Eds.), Advances in the Biology of Shrews, Special Publication of Carnegie Museum of Natural History 18, pp. 1-458.

Jacobs, L.1., 1985. The beginning of the age of the murids in Africa. Acta Zool. Fenn. 170, 149-151.

Janke, A., Xu, X., Arnason, U., 1997. The complete mitochondrial genome of the wallaroo (Macropus robustus) and the phylogenetic relationship among Monotremata, Marsupialia and Eutheria. Proc. Natl. Acd. Sci. 94, 1276-1281.

Juste, J., Alvarez, Y., Tabares, E., Garrido Pertierra, A., Ibanez, C., 1999. Phylogeography of African fruitbats (Megachiroptera). Mol. Phylogenet. Evol. 13, 596-604.
Lewis, P.O., 2001. A likelihood approach to estimating phylogeny from discrete morphological character data. Syst. Biol. 50, 913-925.

Macphee, R.D.E., Novacek, M.J., 1993. Definition and relationships of Lipotyphla. In: Szalay, F., Novacek, M.J., McKenna, M.C. (Eds.), Mammal Phylogeny, Placentals, vol. 2. Springer, New York, pp. 13-31.

Maddalena, T., 1990. Systematics and biogeography of Afrotropical and Paleartic shrews of the genus Crocidura (Insectivora: Soricidae): An electrophoretic approach. In: Peters, G., Hutterer, R. (Eds.), Vertebrates in the Tropics. Museum Alexander Koenig, Bonn, pp. 297-308.

Maddalena, T., Bronner, N., 1992. Biological systematics of the endemic African genus Myosorex Gray, 1838 (Mammalia: Soricidae). Israel J. Zool. 38, 245-252.

Maddalena, T., Ruedi, M., 1994. Chromosomal evolution in the genus Crocidura (Soricidae, Insectivora). In: Merritt, J.F., Kirkland, G.L., Jr.Jr., Rose, R.K. (Eds.), Advances in the Biology of Shrews, 18. Carnegie Mus. Nat. Hist. Spec. Publ., pp. 335-344.

Maddison, W.P., Maddison, D.R., 2004. Mesquite: a modular system for evolutionary analysis. Version 1.06 , mesquiteproject.org.

Maldonado, J.E., Vila, C., Wayne, R.K., 2001. Tripartite genetic subdivisions in the ornate shrew (Sorex ornatus). Mol. Ecol. 10, 127-147.

Mason-Gamer, R.J., Kellogg, E., 1996. Testing for phylogenetic conflict among molecular data sets in the Tribe Triticeae (Gramineae). Syst. Biol. 45, 524-545.

McLellan, L.J., 1994. Evolution and phylogenetic affinities of the African species of Crocidura, Suncus and Sylvisorex (Insectivora: Soricidae). In: Merritt, J.F., Kirkland, G.L., Jr.Jr., Rose, R.K. (Eds.), Advances in the Biology of Shrews, 18. Carnegie Mus. Nat. Hist. Spec. Publ., pp. 379-391.

Meester, J., 1953. The genera of African shrews. Ann. Transvaal Mus. 22, 205-214.

Micheels, A., 2003. Late Miocene climate modelling with Echam4/ML. The effects of the paleovegetation on the Tortonian climate. Doctorat thesis. Geowissenschaftlichen Fakultät der Eberhard-Karls Universität Tübingen.

Minin, V., Abdo, Z., Joyce, P., Sullivan, J., 2003. Performance-based selection of likelihood models for phylogeny estimation. Syst. Biol. 52, 674-683.

Motokawa, M., Suzuki, H., Harada, M., Lin, L.K., Koyasu, K., Oda, S., 2000. Phylogenetic relationships among East Asian species of Crocidura (Mammalia, Insectivora) inferred from mitochondrial cytochrome $b$ gene sequences. Zool. Sci. 17, 497-504.

Murphy, W.J., Eizirik, E., O Brien, S.J., Madsen, O., Scally, M., Douady, C.J., Teeling, E., Ryder, O.A., Stanhope, M.J., de Jong, W.W., Springer, M.S., 2001. Resolution of the early placental mammal radiation using Bayesian phylogenetics. Science 294, 2348-2351.

Ogg, J.G., 2004. Status of divisions of the International Geologic Time Scale. Lethaia 37, 183-199.

Ohdachi, S.D., Dokuchaev, N.E., Hasegawa, M., Masuda, R., 2001. Intraspecific phylogeny and geographical variation of six species of northeastern Asiatic Sorex shrews based on the mitochondrial cytochrome $b$ sequences. Mol. Ecol. 10, 2199-2213.

Ohdachi, S.D., Hasegawa, M., Iwasa, M.A., Vogel, P., Oshida, T., Lin, LK., Abe, H., 2006. Molecular phylogenetics of soricid shrews (Mammalia) based on mitochondrial cytochrome $b$ gene sequences: with special reference to the Soricinae. J. Zool. 270, 177-191.

Ohdachi, S.D., Iwasa, M.A., Nesterenko, V.A., Abe, H., Masuda, R., Haberl, W., 2004. Molecular phylogenetics of Crocidura shrews (Insectivora) in east and central Asia. J. Mammal. 85, 396-403.

Ohdachi, S.D., Masuda, R., Abe, H., Dokuchaev, N.E., 1997. Biogeographical history of northeastern Asiatic soricine shrews (Insectivora, Mammalia). Res. Pop. Ecol. 39, 157-162.

Quérouil, S., Hutterer, R., Barrière, P., Colyn, M., Peterhans, J.C.K., Verheyen, E., 2001. Phylogeny and evolution of African shrews (Mammalia: Soricidae) inferred from 16s rRNA sequences. Mol. Phyl. Evol. 20, 185-195.

Rasmussen, A.S., Arnason, U., 1999. Phylogenetic studies of complete mitochondrial DNA molecules place cartilaginous fishes within the tree of bony fishes. J. Mol. Evol. 48, 118-123. 
Repenning, C.A., 1967. Subfamilies and genera of the Soricidae. U.S. Geol. Surv. Prof. Paper 565, 1-74.

Reumer, J.W.F., 1987. Redefinition of the Soricidae and the Heterosoricidae (Insectivora, Mammalia), with the description of the Crocidosoricinae, a new family of soricidae. Rev. Paléobiol. 6, 189-192.

Reumer, J.W.F., 1989. Speciation and evolution in the Soricidae (Mammalia: Insectivora) in relation with the paleoclimate. Rev. suisse Zool. 96, 81-90.

Reumer, J.W.F., 1994. Phylogeny and distribution of the Crocidosoricinae (Mammalia: Soricidae). In: Merritt, J.F., Kirkland Jr., G.L., Rose, R.K. (Eds.), Advances in the Biology of Shrews, vol. 18. Carnegie Museum of Natural History Spec. Publ., pp. 345-356.

Reumer, J.W.F., 1998. Classification of the fossil and recent shrews. In: Wojcik, J.M., Wolsan, M. (Eds.), Evolution of Shrews. Mammal Research Institute, Polish Academy of Science, Bialowieza, pp. 5-21.

Robinson, P., Black, C.C., 1974. Vertebrate faunas from Neogene of Tunisia. Ann. Geol. Surv. Egpt. 4, 319-332.

Rodriguez, R., Oliver, J.L., Marin, A., Medina, J.R., 1990. The general stochastic model of nucleotide substitution. J. Theor. Bio. 142, 485-501.

Ruedi, M., 1996. Phylogenetic evolution and biogeography of Southeast Asian shrews (genus Crocidura: Soricidae). Biol. J. Linnean Soc. 58, 197-219.

Ruedi, M., Auberson, M., Savolainen, V., 1998. Biogeography of sulawesian shrews: testing for their origin with a parametric bootstrap on molecular data. Mol. Phylogenet. Evol. 9, 567-571.

Ruedi, M., Vogel, P., 1995. Chromosomal evolution and zoogeographic origin of southeast Asian shrews (genus Crocidura). Experientia 51, 174-178.

Rzebik-Kowalska, B., 1998. Fossil history of shrews in Europe. In: Wojcik, J.M., Wolsan, M. (Eds.), Evolution of Shrews. Mammal Research Institute, Polish Academy of Science, Bialowieza, pp. 23-92.

Sanderson, M.J., 1997. A nonparametric approach to estimating divergence times in the absence of rate constancy. Mol. Biol. Evol. 14, 1218-1231.

Sanderson, M.J., 2002. Estimating absolute rates of molecular evolution and divergence times: a penalized likelihood approach. Mol. Biol. Evol. 19, 101-109.

Schlitter, D.A., Hutterer, R., Maddalena, T., Robbins, L.W., 1999. New karyotypes of shrews (Mammalia: Soricidae) from Cameroon and Somalia. Ann. Carnegie Mus. 68, 1-14.

Simpson, G.G., 1945. The principles of classification and a classification of mammals. B. Am. Mus. Nat. Hist. 85, 1-350.

Storch, G., Qiu, Z.H., Zazhigin, V.S., 1998. Fossil history of shrews in Asia. In: Wojcik, J.M., Wolsan, M. (Eds.), Evolution of Shrews. Mammal Research Institute, Polish Academy of Science, Bialowieza, pp. 93-117.

Struck, T.H., Purschke, G., Halanych, K.M., 2006. Phylogeny of Eunicida (Annelida) and exploring data congruence using a partition addition bootstrap alteration (PABA) approach. Syst. Biol. 55, 1-20.

Swofford, D.L., 2001. PAUP* 4.0: Phylogenetic Analyses Using Parsimony (*and other methods). Beta version 4.0b10a for PC. Sinauer Associates, Inc., Publishers, Sunderland, Massachusetts.
Symonds, M.R.E., 2005. Phylogeny and life histories of the 'Insectivora': controversies and consequences. Biol. Rev. 80, 93-128.

Tedford, R.H., Martin, J., 2001. Plionarctos, a tremarctine bear (Ursidae: Carnivora) from western North America. J. Vertebr. Paleontol. 21, 311-321.

Tedford, R.H., Skinner, M.F., Fields, R.W., Rensberger, J.M., Whistler, D.P., Galusha, T., Taylor, B.E., Macdonald, J.R., Webb, S.D., 1987. Faunal succession and biochronology of the Arikareean through Hemphillian interval in North America. In: Woodburne, M.O. (Ed.), Cenozoic Mammals of North America. University of California Press, Berkeley, pp. 153-210.

Thomas, O., 1911. The mammals of the tenth edition of Linnaeus; an attempt to fix the types of the genera and the exact bases and localities of the species. Proc. zool. soc. Lond. 1911, 120-158.

Thomas, H., 1985. The Early and Middle Miocene land connection of the Afro-Arabian plate and Asia: a major event for hominoid dispersal. In: Delson, E. (Ed.), Ancestors: The Hard Evidence. A.R. Liss, New York, pp. 42-50.

Thomas, H., Bernor, R., Jaeger, J.J., 1982. Origine du peuplement mammalien en Afrique du Nord durant le Miocène terminal. Geobios 15, 283-397.

Thompson, J.D., Higgins, D.G., Gibson, T.J., 1994. CLUSTAL W: improving the sensitivity of progressive multiple sequence alignment through sequence weighting, position-specific gap penalties and weight matrix choice. Nucl. Acids Res. 22, 4673-4680.

Thorne, J.L., Kishino, H., 2002. Divergence time and evolutionary rate estimation with multilocus data. Syst. Biol. 51, 689-702 statgen.ncsu.edu/thorne/multidivtime.html

Van der Made, J., Morales, J., Sen, S., Aslan, F., 2002. The first camel from the Upper Miocene of Turkey and the dispersal of the camels into the Old World. C.R. Palevol. 1, 117-122.

Vogel, P., Cosson, J.F., Jurado, L.F.L., 2003. Taxonomic status and origin of the shrews (Soricidae) from the Canary Islands inferred from a mtDNA comparison with the European Crocidura species. Mol. Phylogenet. Evol. 27, 271-282.

Wang, X.M., Wideman, B.C., Nichols, R., Hanneman, D.L., 2004. A new species of Aelurodon (Carnivora, Canidae) from the Barstovian of Montana. J. Vertebr. Paleontol. 24, 445-452.

Webb, S.D., Opdyke, N.D., 1995. Global climatic influence on Cenozoic land mammal faunas. In: Webb, S.D., Opdyke, N.D. (Eds.), Effects of Past Global Change on Life. National Academy Press, Washington, DC, pp. 184-208.

Wheeler, W.C., Ramirez, M.J., Aagesen, L., Schulmelster, S., 2006. Partition-free congruence analysis: implications for sensitivity analysis. Cladistics 22, 256-263.

Yang, Z., 1996. Phylogenetic analysis using parsimony and likelihood methods. J. Mol. Evol. 42, 294-307.

Yoder, A.D., Irwin, J.A., Payseur, B.A., 2001. Failure of the ILD to determine data combinability for slow loris phylogeny. Syst. Biol. 50, 408-424.

Zima, J., Lukacova, L., Macholan, M., 1998. Chromosomal evolution in shrews. In: Wojcik, J.M., Wolsan, M. (Eds.), Evolution of Shrews. Mammal Research Institute, Polish Academy of Science, Bialowieza, pp. $175-210$. 